\title{
Gaseous Hydrocarbon Separations Using Functionalized lonic Liquids
}

\author{
Leila Moura ${ }^{1,2}$, Catherine C. Santini ${ }^{2}$ and Margarida F. Costa Gomes ${ }^{1 *}$ \\ ${ }^{1}$ Clermont Université, Université Blaise Pascal, Institut de Chimie de Clermont-Ferrand, UMR 6296 CNRS, Équipe Thermodynamique et Interactions \\ Moléculaires, ICCF-TIM, BP 80026, 63171 Aubière - France \\ ${ }^{2}$ Université de Lyon, UMR 5265 CNRS, Université de Lyon 1-ESCPE Lyon, C2P2, Équipe Chimie Organométallique de Surface, \\ 69616 Villeurbanne - France \\ e-mail: margarida.c.gomes@univ-bpclermont.fr \\ * Corresponding author
}

\begin{abstract}
The functionalization of the side chains on the cation or the anion of an ionic liquid is a common approach to tailor its properties for different processes including the separation of gases. In this paper, we present the current state of the art concerning the usage of ionic liquids for hydrocarbon separations. We also show how the functionalization of ionic liquids or the appropriate anion/cation combinations can contribute to the increase of the performance of the ionic liquids for the separation of gaseous hydrocarbons - either by improving the capacity of the ionic liquid to absorb a given gas or by increasing the selectivity towards a particular hydrocarbon. Original results concerning the usage of olefin-complexing metal salts of lithium (I), nickel (II) and copper (II) dissolved in ionic liquids for selectively absorbing light olefins are presented. It is observed that the absorption capacity of an imidazolium-based ionic liquid is doubled by the addition of a copper (II) salt. This result is compared with the effect of the functionalization of the ionic liquid and the advantages and difficulties of the two approaches are analyzed.
\end{abstract}

Résumé - Liquides ioniques fonctionnalisés pour la séparation d'hydrocarbures gazeux - La fonctionnalisation des chaînes latérales sur le cation ou l'anion d'un liquide ionique est une approche commune pour adapter ses propriétés pour les différents processus, y compris la séparation de gaz. Dans cet article, nous présentons l'état actuel des recherches concernant l'utilisation de liquides ioniques pour les séparations d'hydrocarbures gazeux. Nous montrons comment la fonctionnalisation de liquides ioniques ou des combinaisons d'anions/cations appropriées peuvent contribuer à l'augmentation de leur performance pour la séparation des hydrocarbures gazeux - soit par l'amélioration de la capacité du liquide ionique pour absorber un gaz donné ou en augmentant la sélectivité pour un hydrocarbure particulier. Des résultats originaux concernant l'utilisation de sels métalliques de lithium (I), le nickel (II) et le cuivre (II) dissous dans des liquides ioniques pour absorber sélectivement des oléfines légères sont présentés. On constate que la capacité d'absorption d'un liquide ionique à base d'imidazolium est doublée par addition d'un sel de cuivre (II). Ce résultat est comparé avec l'effet de la fonctionnalisation du liquide ionique. Les avantages et les difficultés de ces deux approches sont analysés. 


\section{INTRODUCTION}

Separation techniques like distillation, crystallization, liquidliquid extraction or absorption are commonly used and are based on the creation or on the addition of a new phase. They require either an energy transfer or the use of a mass-transfer agent. Changing from an energy-separating agent to a massseparating agent can potentially reduce the process energy requirements, but the selected absorbent should be easy to recycle, have low volatility, and the solubilities of the species to separate should be significantly different. These constraints, together with the need to obey tougher environmental regulations, render the choice of the absorbent difficult.

Membranes make use of liquid or solid (frequently polymeric) barriers to separate species that present different permeability. Membranes are used in small, compact and clean units that require low energy to achieve separation, but are still difficult to scale-up. Adsorption is a surface-based process that frequently relies on a solid agent to achieve separation. The separation is achieved due to different interacting forces at the interface (originating physisorption or chemisorption processes) that selectively interacts with certain components in detriment of others from a liquid or gas mixture. The adsorbent material should have high surface area, good mechanical properties, fast adsorption kinetics and the ability to be regenerated without loss of its properties. Commonly used supports are alumina, ion exchanging resins, high-surface-area silica zeolites and molecular sieves. Electrophoresis and centrifugation are examples of separation techniques that exploit the differences in the responses of the constituents of a feed to an external force or gradient. They are especially useful and versatile for separating biochemical [1]. Cryogenic distillation is used for the separation of large volumes of hydrocarbon gases (i.e. ethane/ethylene or propane/propylene) and is viewed as an expensive, energy demanding process whose replacement by a more economic and environmentally friendly alternative performance would represent a major advance in the field.

\section{IONIC LIQUIDS AS SEPARATING AGENTS}

Ionic liquids have been suggested as new separating agents for gaseous hydrocarbon separations namely for olefin/ paraffin gas separation. They can also act as absorbents or as solvents for the chemical complexation of olefins with silver or copper salts. Ionic liquids are composed uniquely of ions and have a melting point below $100^{\circ} \mathrm{C}$. Many present unique properties such as negligible vapor pressure, high thermal, chemical and electrochemical stability, flame retardant effect, and high ionic conductivity. Ionic liquid are also called "designer solvents" due to the large variety of combination possibilities of cations and anions, leading to tunable physical chemical properties.

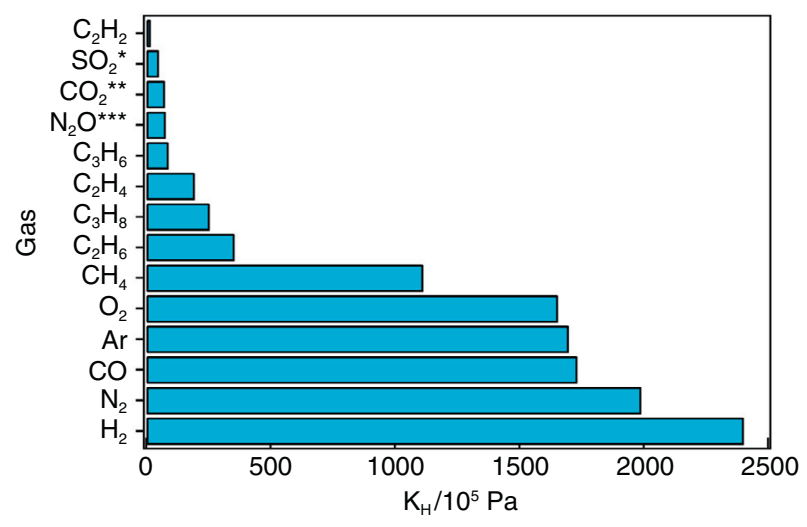

Figure 1

Henry's law constant, $K_{H}$, for several gases in ionic liquid $\left[\mathrm{C}_{1} \mathrm{C}_{4} \mathrm{Im}\right]\left[\mathrm{BF}_{4}\right]$ at $313 \mathrm{~K} . * 293 \mathrm{~K} ; * * 314 \mathrm{~K} ; * * * 298 \mathrm{~K}[2]$.

In Figure 1, are shown the Henry's law constants, $K_{H}$, of different gases in one ionic liquid - 1-butyl-3-methylimidazolium tetrafluoroborate, $\left[\mathrm{C}_{1} \mathrm{C}_{4} \mathrm{Im}\right]\left[\mathrm{BF}_{4}\right]-[2]$. As can be observed, the mole fraction solubility spans over more than two orders of magnitude, depending on the nature of the gas. These differences can be explored by proposing some ionic liquids as selective absorbents for gases.

Monoatomic, diatomic, non-polar or gases with low polarizability present the lowest solubilities in the ionic liquid $\left[\mathrm{C}_{1} \mathrm{C}_{4} \mathrm{Im}\right]\left[\mathrm{BF}_{4}\right]$. Unsaturated hydrocarbons frequently present a higher solubility in ionic liquids than their saturated counterparts and so these fluids are considered promising for saturated/unsaturated hydrocarbon separation. The exact reasons for the observed trends are still poorly understood, even if they are essential for the development of new gas separation processes $[3,4]$.

The functionalization of the side chains or the modification of the ionic liquid anion are popular approaches to tailor its properties for particular applications such in catalysis [5], energy storage [6], capture of carbon dioxide [3] and in separation technology [7]. In this work, we have studied the possibility of using ionic liquids for the separation of light saturated and unsaturated hydrocarbons and have started by compiling the literature results on the solubility of ethane and ethylene in different ionic liquids formed by the cations and anions in Table 1 . The Henry's law constants for ethane and ethylene are reported in Figure 2 [2, 8-26] and Table 2 [2, 8-26].

\section{FUNCTIONALIZATION OF THE IONIC LIQUIDS}

There are few examples of an experimental rational approach for the design of an ionic liquid to optimize the 
Oil \& Gas Science and Technology - Rev. IFP Energies nouvelles (2016) 71, 23

TABLE 1

Abbreviation, full designation and structure of some cations of ionic liquids. $\mathrm{C}_{n / m}$ represent alkyl chains of variable size. In the anions, $\mathrm{R}_{n}$ represents alkyl chains of variable size

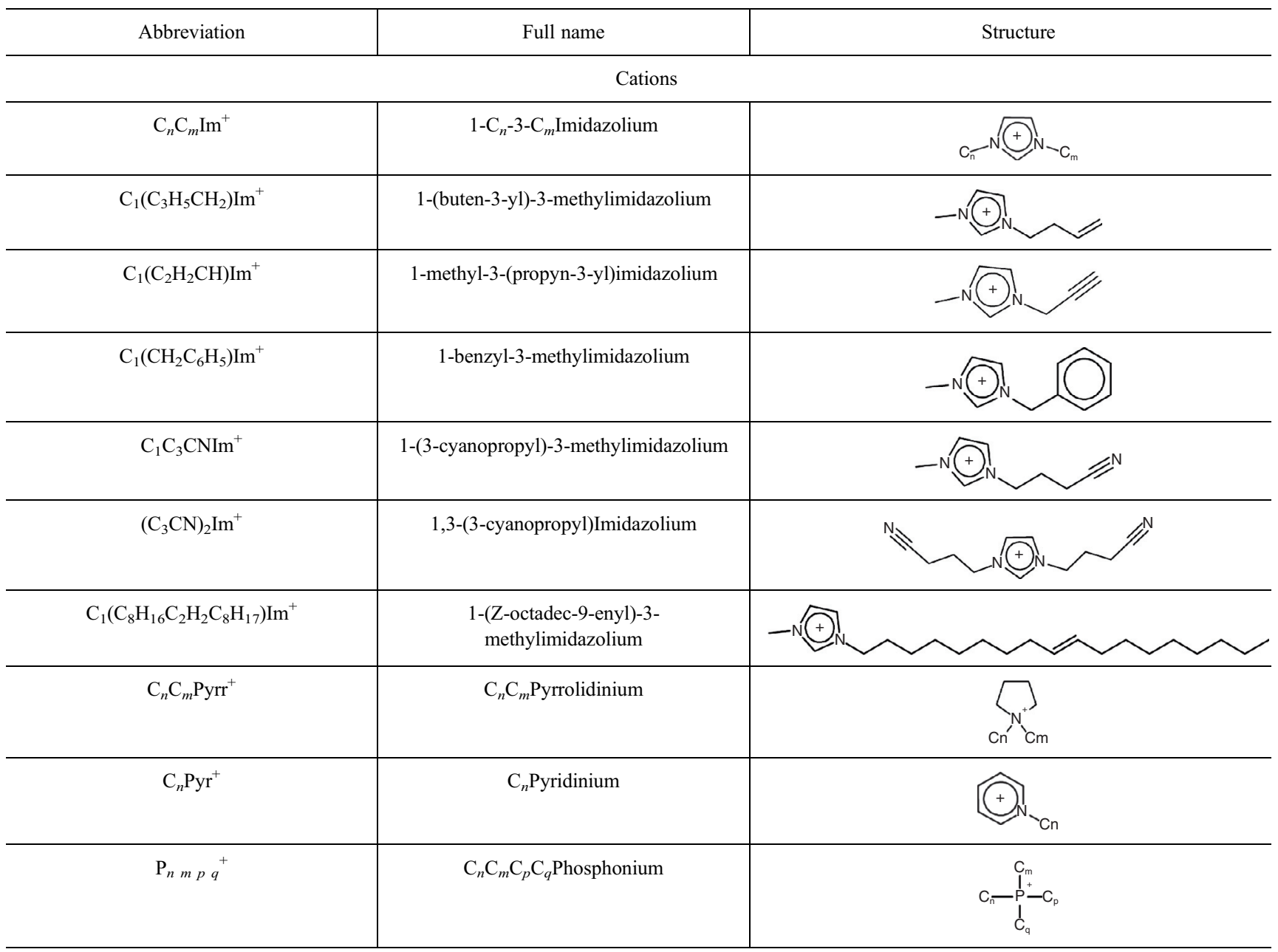

Anions

\begin{tabular}{|c|c|c|}
\hline $\mathrm{NTf}_{2}^{-}$ & Bis(trifluoromethylsulfonyl)imide & $\mathrm{F}_{3} \mathrm{C}, \stackrel{\mathrm{O}}{ } \mathrm{O}_{11}$ \\
\hline $\mathrm{DCA}^{-}$ & Dicyanamide & \\
\hline $\mathrm{C}_{n} \mathrm{HPO}_{3}^{-}$ & $\mathrm{C}_{n}$ Phosphite & \\
\hline $\mathrm{PF}_{6}^{-}$ & Hexafluorophosphate & \\
\hline $\mathrm{CF}_{3} \mathrm{SO}_{3}^{-}$ & Trifluromethanesulfonate & \\
\hline $\mathrm{BF}_{4}^{-}$ & Tetrafluoroborate & \\
\hline
\end{tabular}


TABLE 1 (continued)

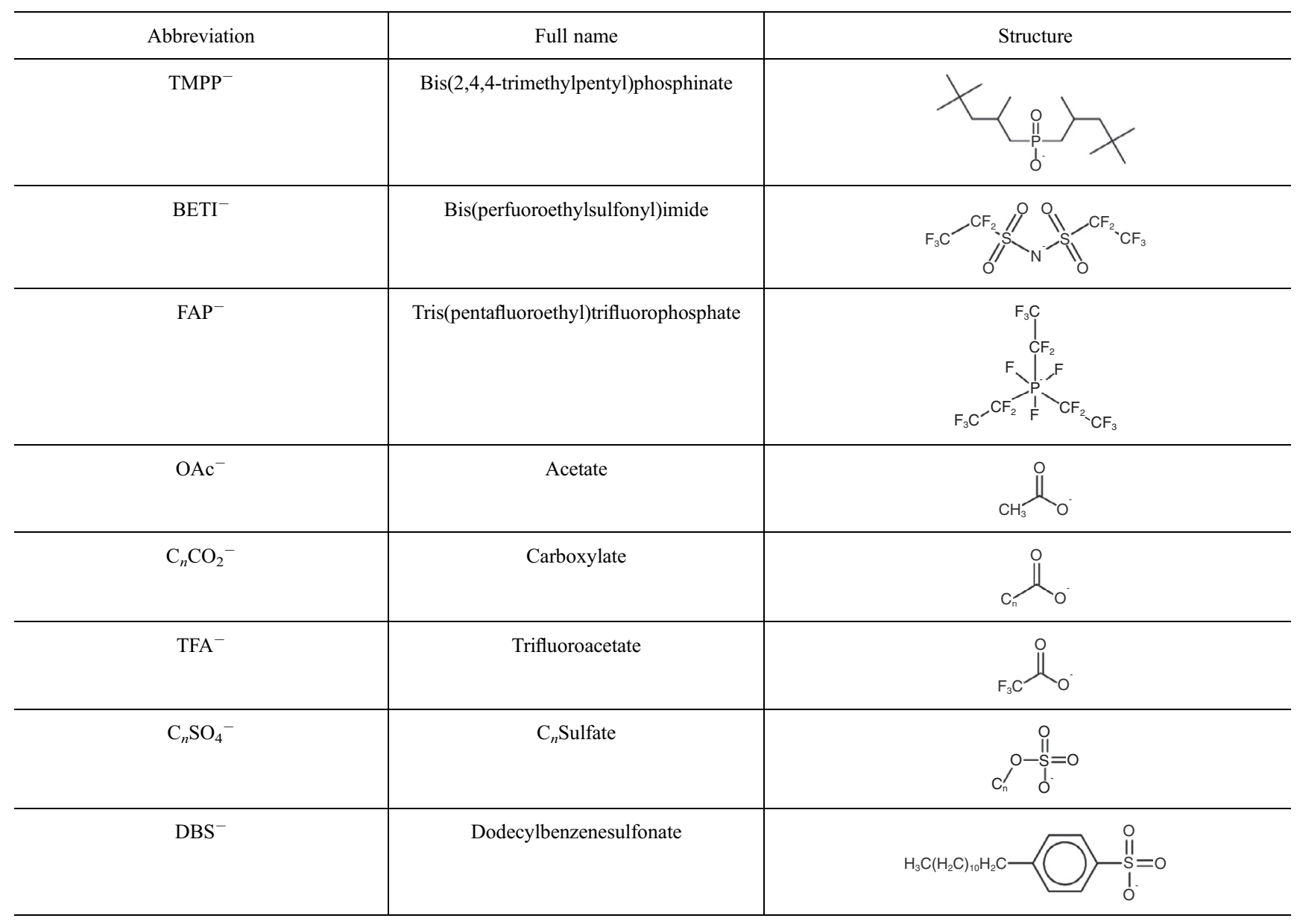

solubility of one of the gases in the separation of ethane/ ethylene or propane/propene. Moura et al. [27, 28] have selected several functionalized ionic liquids designed to maximize the solubility and interactions of ethylene in the ionic liquid in detriment of the solubility of ethane. The functionalizations used were the increasing alkyl side-chain on the cation of the ionic liquid $\left(\left[\mathrm{C}_{1} \mathrm{C}_{4} \mathrm{Im}\right]\left[\mathrm{NTf}_{2}\right]\right.$ and $\left.\left[\mathrm{C}_{1} \mathrm{C}_{8} \mathrm{Im}\right]\left[\mathrm{NTf}_{2}\right]\right)$; unsaturations on the alkyl side-chain on the cation of the ionic liquid $\left(\left[\mathrm{C}_{1}\left(\mathrm{C}_{2} \mathrm{H}_{2} \mathrm{CH}\right) \operatorname{Im}\right]\left[\mathrm{NTf}_{2}\right]\right.$, $\left[\mathrm{C}_{1}\left(\mathrm{C}_{3} \mathrm{H}_{5} \mathrm{CH}_{2}\right) \mathrm{Im}\right]\left[\mathrm{NTf}_{2}\right]$ and $\left.\left[\mathrm{C}_{1}\left(\mathrm{CH}_{2} \mathrm{C}_{6} \mathrm{H}_{5}\right) \mathrm{Im}\right]\left[\mathrm{NTf}_{2}\right]\right)$; cyano groups in the cation or anion of the ionic liquid or both $\left(\left[\mathrm{C}_{1} \mathrm{C}_{3} \mathrm{CNIm}\right]\left[\mathrm{NTf}_{2}\right], \quad\left[\mathrm{C}_{1} \mathrm{C}_{3} \mathrm{CNIm}\right][\mathrm{DCA}]\right.$ and $\left[\mathrm{C}_{1} \mathrm{C}_{4} \mathrm{Im}\right]$ [DCA]) and a phosphite based anion in the ionic liquid $\left(\left[\mathrm{C}_{1} \mathrm{C}_{4} \mathrm{Im}\right]\left[\mathrm{C}_{1} \mathrm{HPO}_{3}\right]\right)$. The authors observed that small changes in the structure of the ionic liquid can have large effects in the ethane and ethylene solubility as illustrated in Figure 2 and can significantly influence the ideal selectivity of ethylene as shown in Figure 3 [9-26, 28, 29].

Adding unsaturations in the alkyl chain of the cation of the ionic liquid, cyano groups in the alkyl chain of the cation or anion and changing the anion of the ionic liquid from an $\mathrm{NTf}_{2}{ }^{-}$to a $\mathrm{C}_{1} \mathrm{HPO}_{3}{ }^{-}$or DCA, lead to decreases in the

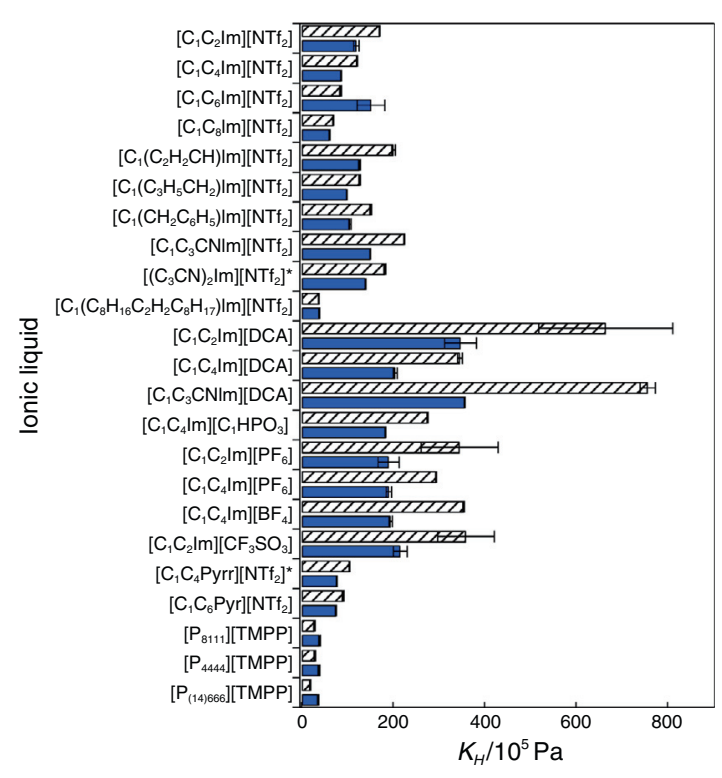

Figure 2

Henry's constant, $K_{H}$, of ethane (empty bars) and ethylene (full bars) in the ionic liquids at $313 \mathrm{~K}$ (* at $303 \mathrm{~K}$ ) (Tab. 2)[2, 8-26]. 
TABLE 2

\begin{tabular}{|c|c|}
\hline Ionic liquid & References \\
\hline$\left[\mathrm{C}_{1} \mathrm{C}_{2} \operatorname{Im}\right]\left[\mathrm{NTf}_{2}\right]$ & {$[8-14]$} \\
\hline$\left[\mathrm{C}_{1} \mathrm{C}_{4} \operatorname{Im}\right]\left[\mathrm{NTf}_{2}\right]$ & {$[9,15-20]$} \\
\hline$\left[\mathrm{C}_{1} \mathrm{C}_{6} \mathrm{Im}\right]\left[\mathrm{NTf}_{2}\right]^{*}$ & {$[15,16,21]$} \\
\hline$\left[\mathrm{C}_{1} \mathrm{C}_{8} \mathrm{Im}\right]\left[\mathrm{NTf}_{2}\right]$ & [10] \\
\hline$\left[\mathrm{C}_{1}\left(\mathrm{C}_{2} \mathrm{H}_{2} \mathrm{CH}\right) \operatorname{Im}\right]\left[\mathrm{NTf}_{2}\right]$ & {$[10]$} \\
\hline$\left[\mathrm{C}_{1}\left(\mathrm{C}_{3} \mathrm{H}_{5} \mathrm{CH}_{2}\right) \mathrm{Im}\right]\left[\mathrm{NTf}_{2}\right]$ & [9] \\
\hline$\left[\mathrm{C}_{1}\left(\mathrm{CH}_{2} \mathrm{C}_{6} \mathrm{H}_{5}\right) \mathrm{Im}\right]\left[\mathrm{NTf}_{2}\right]$ & [9] \\
\hline$\left[\mathrm{C}_{1} \mathrm{C}_{3} \mathrm{CNIm}\right]\left[\mathrm{NTf}_{2}\right]^{*}$ & {$[10,19,21,22]$} \\
\hline$\left[\left(\mathrm{C}_{3} \mathrm{CN}\right)_{2} \operatorname{Im}\right]\left[\mathrm{NTf}_{2}\right]^{*}$ & [19] \\
\hline$\left[\mathrm{C}_{1}\left(\mathrm{C}_{8} \mathrm{H}_{16} \mathrm{C}_{2} \mathrm{H}_{2} \mathrm{C}_{8} \mathrm{H}_{17}\right) \operatorname{Im}\right]\left[\mathrm{NTf}_{2}\right]$ & [23] \\
\hline$\left[\mathrm{C}_{1} \mathrm{C}_{2} \operatorname{Im}\right][\mathrm{DCA}]$ & {$[12,21]$} \\
\hline$\left[\mathrm{C}_{1} \mathrm{C}_{4} \operatorname{Im}\right][\mathrm{DCA}]$ & [10] \\
\hline$\left[\mathrm{C}_{1} \mathrm{C}_{3} \mathrm{CNIm}\right][\mathrm{DCA}]$ & [10] \\
\hline$\left[\mathrm{C}_{1} \mathrm{C}_{4} \operatorname{Im}\right]\left[\mathrm{C}_{1} \mathrm{HPO}_{3}\right]$ & [10] \\
\hline$\left[\mathrm{C}_{1} \mathrm{C}_{2} \operatorname{Im}\right]\left[\mathrm{PF}_{6}\right]$ & {$[12]$} \\
\hline$\left[\mathrm{C}_{1} \mathrm{C}_{4} \mathrm{Im}\right]\left[\mathrm{PF}_{6}\right]^{*}$ & {$[15-17,19-22,24]$} \\
\hline$\left[\mathrm{C}_{1} \mathrm{C}_{4} \operatorname{Im}\right]\left[\mathrm{BF}_{4}\right]$ & {$[2,12,21,24]$} \\
\hline$\left[\mathrm{C}_{1} \mathrm{C}_{2} \mathrm{Im}\right]\left[\mathrm{CF}_{3} \mathrm{SO}_{3}\right]$ & [12] \\
\hline$\left[\mathrm{C}_{1} \mathrm{C}_{4} \mathrm{Pyrr}\right]\left[\mathrm{NTf}_{2}\right]$ & {$[12,24]$} \\
\hline$\left[\mathrm{C}_{6} \mathrm{Pyr}\right]\left[\mathrm{NTf}_{2}\right]$ & [24] \\
\hline$\left[\mathrm{P}_{8111}\right][\mathrm{TMPP}]$ & {$[25]$} \\
\hline$\left[\mathrm{P}_{4444}\right][\mathrm{TMPP}]$ & [25] \\
\hline$\left[\mathrm{P}_{(14) 666}\right][\mathrm{TMPP}]$ & [25] \\
\hline
\end{tabular}

solubility of ethane and ethylene, when compared to a reference ionic liquid, $\left[\mathrm{C}_{1} \mathrm{C}_{4} \mathrm{Im}\right]\left[\mathrm{NTf}_{2}\right]$ (Fig. 2). The only exception is for $\left[\mathrm{C}_{1}\left(\mathrm{C}_{3} \mathrm{H}_{5} \mathrm{CH}_{2}\right) \operatorname{Im}\right]\left[\mathrm{NTf}_{2}\right]$, where ethane solubility is not greatly affected. These modifications in the ionic liquids also lead to increases in the ethane/ethylene separation selectivity (Fig. 3). The solubility of ethane is more affected by changes in the ionic liquid than that of ethylene. For example, increasing the alkyl side chain of the cation from $\left[\mathrm{C}_{1} \mathrm{C}_{4} \mathrm{Im}\right]\left[\mathrm{NTf}_{2}\right]$ to $\left[\mathrm{C}_{1} \mathrm{C}_{8} \operatorname{Im}\right]\left[\mathrm{NTf}_{2}\right]$ leads to an increase in both the ethane and the ethylene solubility but the increase is larger for the saturated gas. The only exceptions are for the ionic liquid containing a double bond in the alkyl sidechain of the cation (where the solubility of ethane is similar and the solubility of ethylene decreases $14 \%$ ) and that

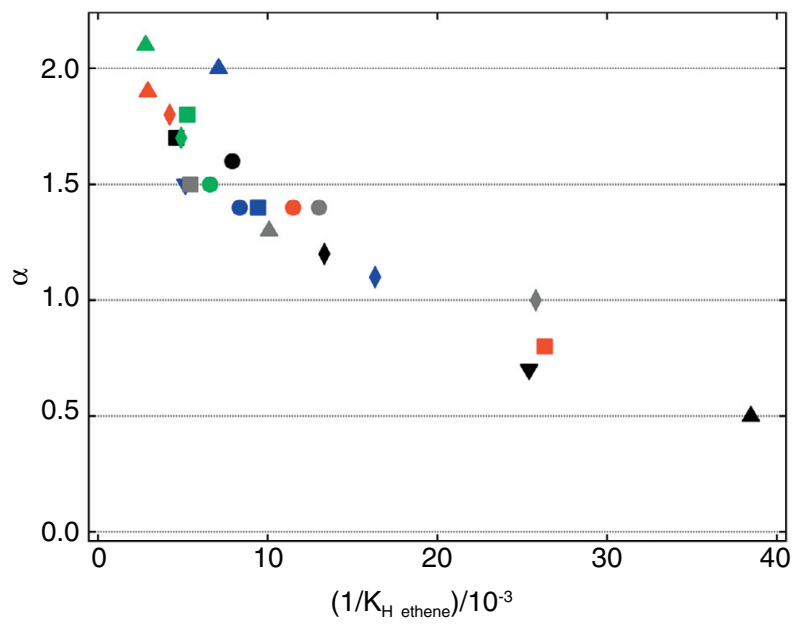

\begin{tabular}{|c|c|c|}
\hline$\bullet$ & {$\left[\mathrm{C}_{1} \mathrm{C}_{2} \mathrm{Im}\right]\left[\mathrm{NTf}_{2}\right]$} & {$[11-13,15-17]$} \\
\hline$\bullet$ & {$\left[\mathrm{C}_{1}\left(\mathrm{C}_{2} \mathrm{H}_{2} \mathrm{CH}\right) \operatorname{Im}\right]\left[\mathrm{NTf}_{2}\right]$} & [10] \\
\hline$\bullet$ & {$\left[\mathrm{C}_{1} \mathrm{C}_{4} \mathrm{Im}\right]\left[\mathrm{NTf}_{2}\right]$} & {$[9,18-22,24]$} \\
\hline$\downarrow$ & {$\left[\mathrm{C}_{1} \mathrm{C}_{8} \operatorname{Im}\right]\left[\mathrm{NTf}_{2}\right]$} & [10] \\
\hline $\boldsymbol{\Delta}$ & {$\left[\mathrm{C}_{1}\left(\mathrm{C}_{3} \mathrm{H}_{5} \mathrm{CH}_{2}\right) \mathrm{Im}\right]\left[\mathrm{NTf}_{2}\right]$} & [9] \\
\hline $\mathbf{\square}$ & {$\left[\mathrm{C}_{1}\left(\mathrm{CH}_{2} \mathrm{C}_{6} \mathrm{H}_{5}\right) \operatorname{Im}\right]\left[\mathrm{NTf}_{2}\right]$} & [9] \\
\hline • & {$\left[\mathrm{C}_{1} \mathrm{C}_{3} \mathrm{CNIm}\right]\left[\mathrm{NTf}_{2}\right]^{*}$} & {$[10,19,21,22]$} \\
\hline $\boldsymbol{\Delta}$ & {$\left[\mathrm{C}_{1} \mathrm{C}_{3} \mathrm{CNIm}\right][\mathrm{DCA}]$} & [10] \\
\hline $\boldsymbol{\Delta}$ & {$\left[\left(\mathrm{C}_{3} \mathrm{CN}\right)_{2} \mathrm{Im}\right]\left[\mathrm{NTf}_{2}\right]^{*}$} & [10] \\
\hline $\bar{\Delta}$ & {$\left[\mathrm{C}_{1}\left(\mathrm{C}_{8} \mathrm{H}_{16} \mathrm{C}_{2} \mathrm{H}_{2} \mathrm{C}_{8} \mathrm{H}_{17}\right) \mathrm{Im}\right]\left[\mathrm{NTf}_{2}\right]$} & [23] \\
\hline 口 & {$\left[\mathrm{C}_{1} \mathrm{C}_{2} \mathrm{Im}\right]\left[\mathrm{PF}_{6}\right]$} & [12] \\
\hline$\nabla$ & {$\left[\mathrm{C}_{1} \mathrm{C}_{4} \mathrm{Im}\right]\left[\mathrm{PF}_{6}\right]^{*}$} & {$[15-17,19-21,24,28]$} \\
\hline - & {$\left[\mathrm{C}_{1} \mathrm{C}_{4} \mathrm{Im}\right]\left[\mathrm{C}_{1} \mathrm{HPO}_{3}\right]$} & [10] \\
\hline $\boldsymbol{\Delta}$ & {$\left[\mathrm{C}_{1} \mathrm{C}_{2} \mathrm{Im}\right][\mathrm{DCA}]$} & {$[12,21]$} \\
\hline$\downarrow$ & {$\left[\mathrm{C}_{1} \mathrm{C}_{4} \mathrm{Im}\right][\mathrm{DCA}]$} & {$[10]$} \\
\hline$\checkmark$ & {$\left[\mathrm{C}_{1} \mathrm{C}_{4} \operatorname{Im}\right]\left[\mathrm{BF}_{4}\right]$} & {$[12,21,24]$} \\
\hline $\mathbf{\square}$ & {$\left[\mathrm{C}_{1} \mathrm{C}_{2} \mathrm{Im}\right]\left[\mathrm{CF}_{3} \mathrm{SO}_{3}\right]$} & [12] \\
\hline$\nabla$ & {$\left[\mathrm{P}_{8111}\right][\mathrm{TMPP}]$} & {$[25]$} \\
\hline 口 & {$\left[\mathrm{P}_{4444}\right][\mathrm{TMPP}]$} & {$[14]$} \\
\hline $\boldsymbol{\Delta}$ & {$\left[\mathrm{P}_{(14) 666}\right][$ TMPP $]$} & [26] \\
\hline$\bullet$ & {$\left[\mathrm{C}_{1} \mathrm{C}_{4} \mathrm{Pyrr}\right]\left[\mathrm{NTf}_{2}\right]$} & {$[12,24]$} \\
\hline$\diamond$ & {$\left[\mathrm{C}_{6} \mathrm{Pyr}\right]\left[\mathrm{NTf}_{2}\right]$} & [29] \\
\hline
\end{tabular}

Figure 3

Ethane/ethylene ideal selectivity versus Henry's constant, $K_{H}$, of ethylene in the ionic liquids at $313 \mathrm{~K}$ (* at $303 \mathrm{~K}$ ).

containing a benzyl group (where the solubility of both gases decreases in a similar way). The authors also found the ionic liquid with the highest separation selectivity for the ethane/ ethylene reported in the literature $-\left[\mathrm{C}_{1} \mathrm{C}_{3} \mathrm{CNIm}\right][\mathrm{DCA}]$.

Green et al. [29] determined the solubilities of ethane and ethylene in an imidazolium based ionic liquid, with an 18 carbon long alkyl side chain, $\left[\mathrm{C}_{1}\left(\mathrm{C}_{8} \mathrm{H}_{16} \mathrm{C}_{2} \mathrm{H}_{2} \mathrm{C}_{8} \mathrm{H}_{17}\right) \mathrm{Im}\right]$ $\left[\mathrm{NTf}_{2}\right]$, designed to have increased solubility for the nonpolar species. For this ionic liquid and for ionic liquids with large nonpolar content, the solubility of ethane or propane is slightly higher than that of their unsaturated counterparts (Fig. 2; Fig. 4, [11-22, 24, 26]), in contrast to the relative 


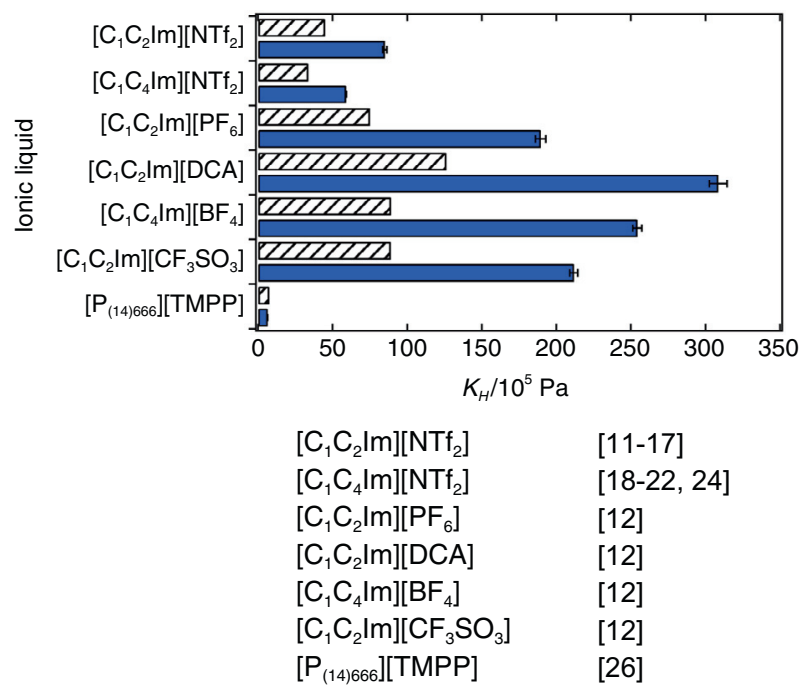

Figure 4

Henry's constant, $K_{H}$, of propane (empty bars) and propene (full bars) in the ionic liquids at $313 \mathrm{~K}$ (* at $303 \mathrm{~K}$ ).

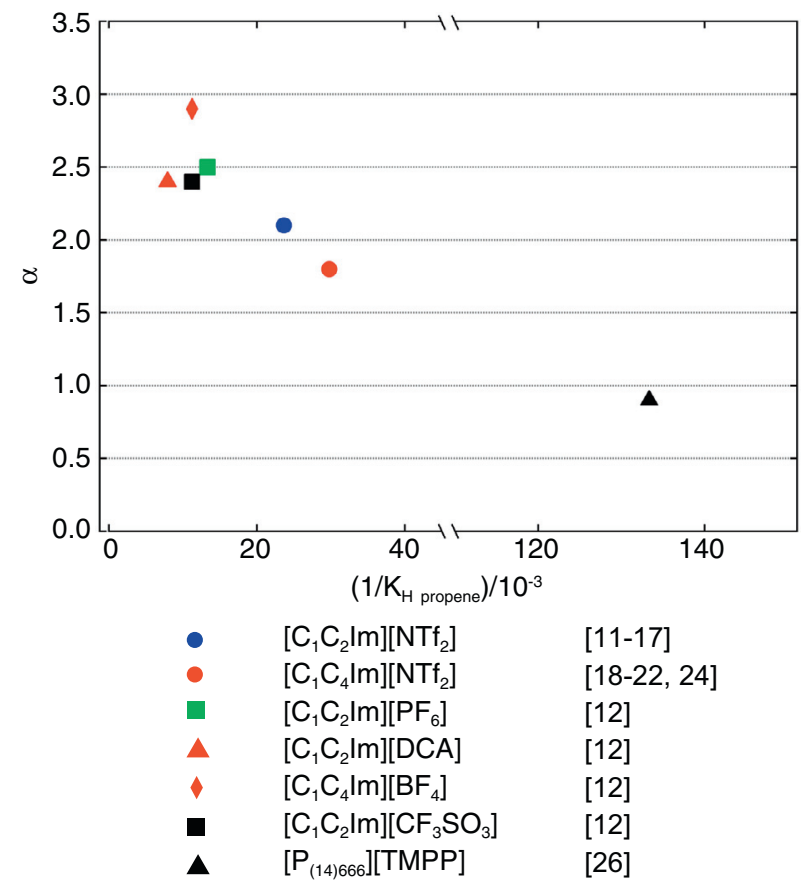

Figure 5

Propane/propene ideal selectivity versus Henry's constant, $K_{H}$, of propene in the ionic liquids at $313 \mathrm{~K}$ (* at $303 \mathrm{~K})$.

solubilities in conventional, more polar ionic liquids. The same observation was made for phosphonium-based ionic liquids:
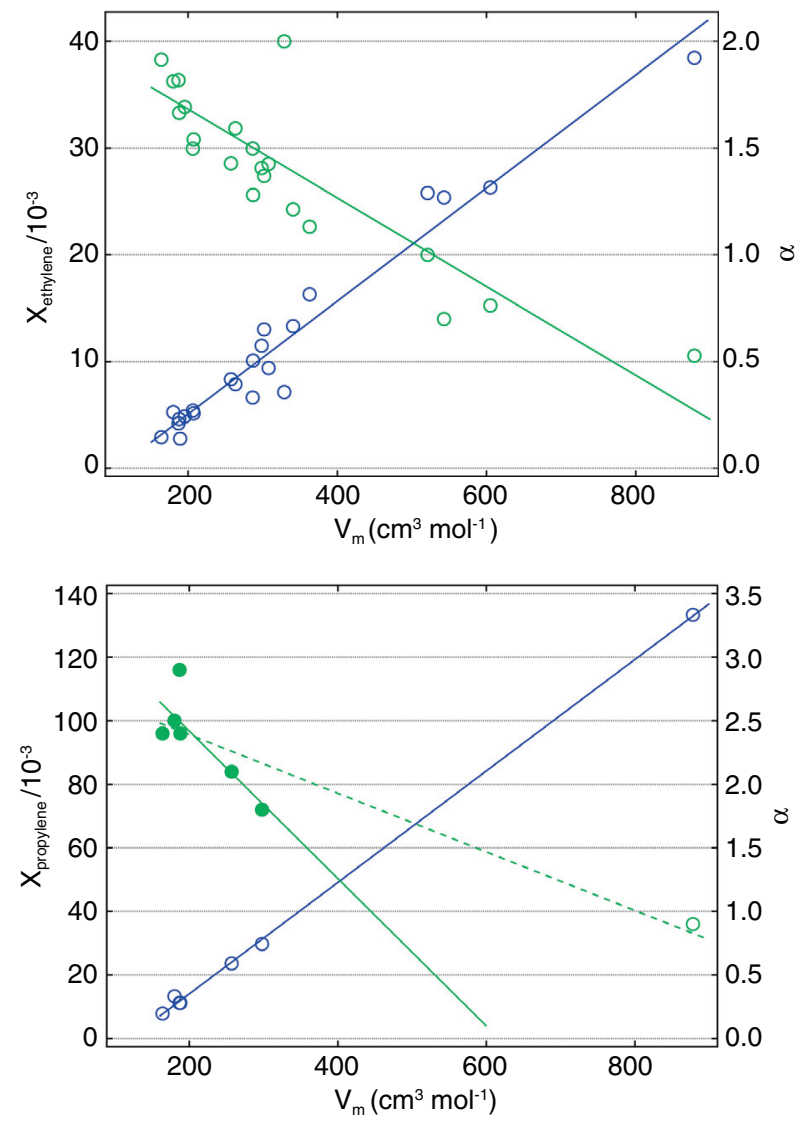

Figure 6

Upper plot: mole fraction absorption capacity for ethylene $\left(x_{\text {ethylene }}\right)$ in blue and ionic liquid ideal separation selectivity for ethane/ethylene $(\alpha)$ in green versus the molar volume $\left(V_{m}\right)$, in $\mathrm{cm}^{3} \cdot \mathrm{mol}^{-1}$, of the ionic liquids. Lower plot: mole fraction absorption capacity for propylene ( $\left.x_{\text {propylene }}\right)$ in light green and ionic liquid's ideal separation selectivity for propane/propylene $(\alpha)$ in blue versus the molar volume $\left(V_{m}\right)$, in $\mathrm{cm}^{3} \cdot \mathrm{mol}^{-1}$, of the ionic liquids. The lines represent the simple linear regression of the data. In the lower plot, the full green line corresponds to the full circles and the dotted line includes also the open circle.

- $\left[\mathrm{P}_{8111}\right][$ TMPP] [23],

$-\left[\mathrm{P}_{4444}\right][\mathrm{TMPP}][25]$,

- $\left[\mathrm{P}_{(14) 666}\right][\mathrm{TMPP}][14]$,

(Fig. 2) by Liu et al. for the separation of ethane and ethylene and for the separation of propane and propene in $\left[\mathrm{P}_{(14) 666}\right]$ [TMPP] [26](Fig. 4). $\left[\mathrm{P}_{(14) 666}\right][$ TMPP] presents the lowest selectivity for the ethane/ethylene and propane/propene separation.

For both separations in the studied ionic liquids we observe that the selectivity increases with the decrease of the solubility of the unsaturated gas. (Fig. 3; Fig. 5, $[11-22,24,26])$. These results indicate that the solubility 

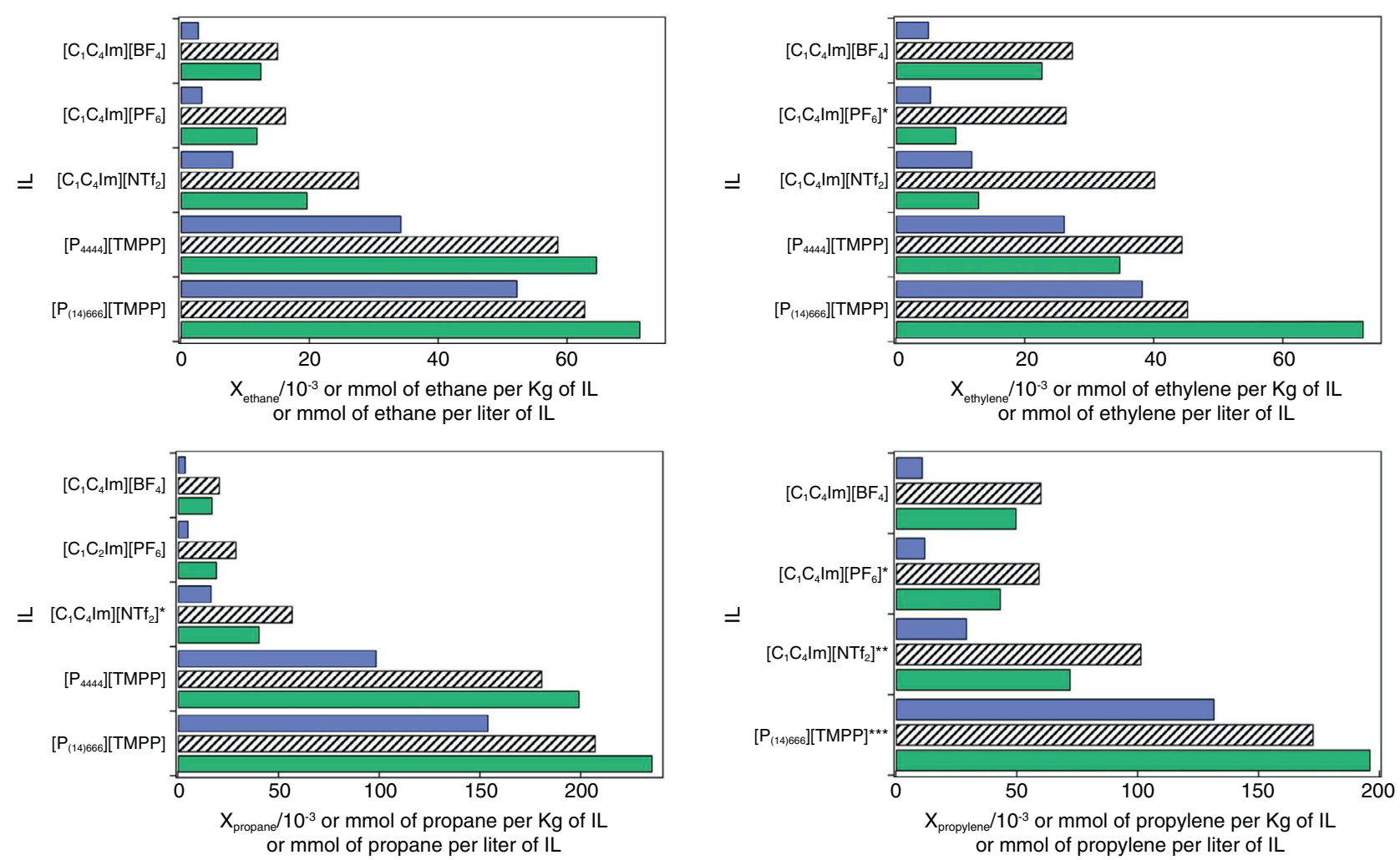

Figure 7

Upper plots: mole fraction $\left(\times 10^{3}\right.$, blue bars), quantity of gas per mass of solvent $\left(\times 10^{4}\right.$, patterned bars) or per volume of solvent (green bars) of ethane (on the left) and ethylene (on the right) for different ionic liquids. Lower plots: mole fraction $\left(\times 10^{3}\right.$, blue bars), quantity of gas per mass of solvent $\left(\times 10^{4}\right.$, patterned bars) or per volume of solvent (green bars) of propane (on the left) and propylene (on the right) for different ionic liquids. All the values refer to 1 bar partial pressure of gas and $313 \mathrm{~K}$ (* values at $320 \mathrm{~K}$ ).

of ethane, ethylene, propane and propylene in the ionic liquids tested are controlled by non-specific interactions, even for ionic liquids containing side-chain functionalization designed to optimize the interactions with one of the hydrocarbons to be separated. This can be further confirmed in Figure 6 since the ionic liquids that present higher ethylene or propene absorption capacity and lower ideal selectivity are the ones with highest molar volume and vice-versa.

\section{IONIC LIQUIDS WITH COMPLEXING AGENTS}

Certain metal transition cations, such as $\mathrm{Cu}(\mathrm{I})$ or $\mathrm{Ag}(\mathrm{I})$ are able to form $\pi$-complexes with unsaturated hydrocarbons. The metal and alkene act as an electron donor and acceptor, forming a coordinative bond if the orbitals involved present the correct symmetry and if the metal possesses high electron affinity for good $\sigma$-bond accepting properties and low promotion energy for good $\pi$-backbonding [26]. This complexation reaction is used to increase the absorption capacity of the ionic liquid for unsaturated light hydrocarbons.
The influence in ethylene solubility of the presence of three different cations, lithium (I), nickel (II) and copper (II) in $\left[\mathrm{C}_{1}\left(\mathrm{CH}_{2} \mathrm{C}_{6} \mathrm{H}_{5}\right) \mathrm{Im}\right]\left[\mathrm{NTf}_{2}\right]$ ionic liquid was studied by Moura [30]. The authors concluded that cations such as lithium and nickel slightly affect the solubility of ethylene. The addition of copper salts almost doubles the absorption capacity of ethylene in the ionic liquid $\left[\mathrm{C}_{1}\left(\mathrm{CH}_{2} \mathrm{C}_{6} \mathrm{H}_{5}\right) \operatorname{Im}\right]\left[\mathrm{NTf}_{2}\right]$, a value compatible with the ones reported in the literature for other metallic cations [31, 32].

Sanchéz et al. [31] studied the absorption of ethane and ethylene in silver salt solutions with the ionic liquids:

- $\left[\mathrm{C}_{1} \mathrm{C}_{2} \operatorname{Im}\right]\left[\mathrm{NTf}_{2}\right]$,

- $\left[\mathrm{C}_{1} \mathrm{C}_{2} \mathrm{Im}\right]\left[\mathrm{CF}_{3} \mathrm{SO}_{3}\right]$,

$-\left[\mathrm{C}_{1} \mathrm{C}_{4} \mathrm{Im}\right]\left[\mathrm{NO}_{3}\right]$,

- $\left[\mathrm{C}_{0} \mathrm{C}_{2} \mathrm{Im}\right]\left[\mathrm{NO}_{3}\right]$,

- $\left[\mathrm{C}_{1} \mathrm{C}_{2-\mathrm{OH}} \mathrm{Im}\right]\left[\mathrm{NO}_{3}\right]$,

- [4-butyl- $\left.\mathrm{C}_{4} \mathrm{Pyr}\right]\left[\mathrm{NO}_{3}\right]$,

- $\left[\mathrm{N}_{1112-\mathrm{OH}}\right]\left[\mathrm{NO}_{3}\right]$,

with $\mathrm{Ag}^{+}$concentrations ranging from 0.45 mol. $\mathrm{L}^{-1}$ to $4.4 \mathrm{~mol} . \mathrm{L}^{-1}$. The results were compared to the solubility of ethane and ethylene in $\left[\mathrm{C}_{1} \mathrm{C}_{2} \mathrm{Im}\right]\left[\mathrm{NTf}_{2}\right]$. The authors 
TABLE 3

Solubility of ethane, ethylene, propane and propylene in several ionic liquids expressed in Henry's law constant, $\mathrm{K}_{\mathrm{H}}$, the majority at $313 \mathrm{~K}$

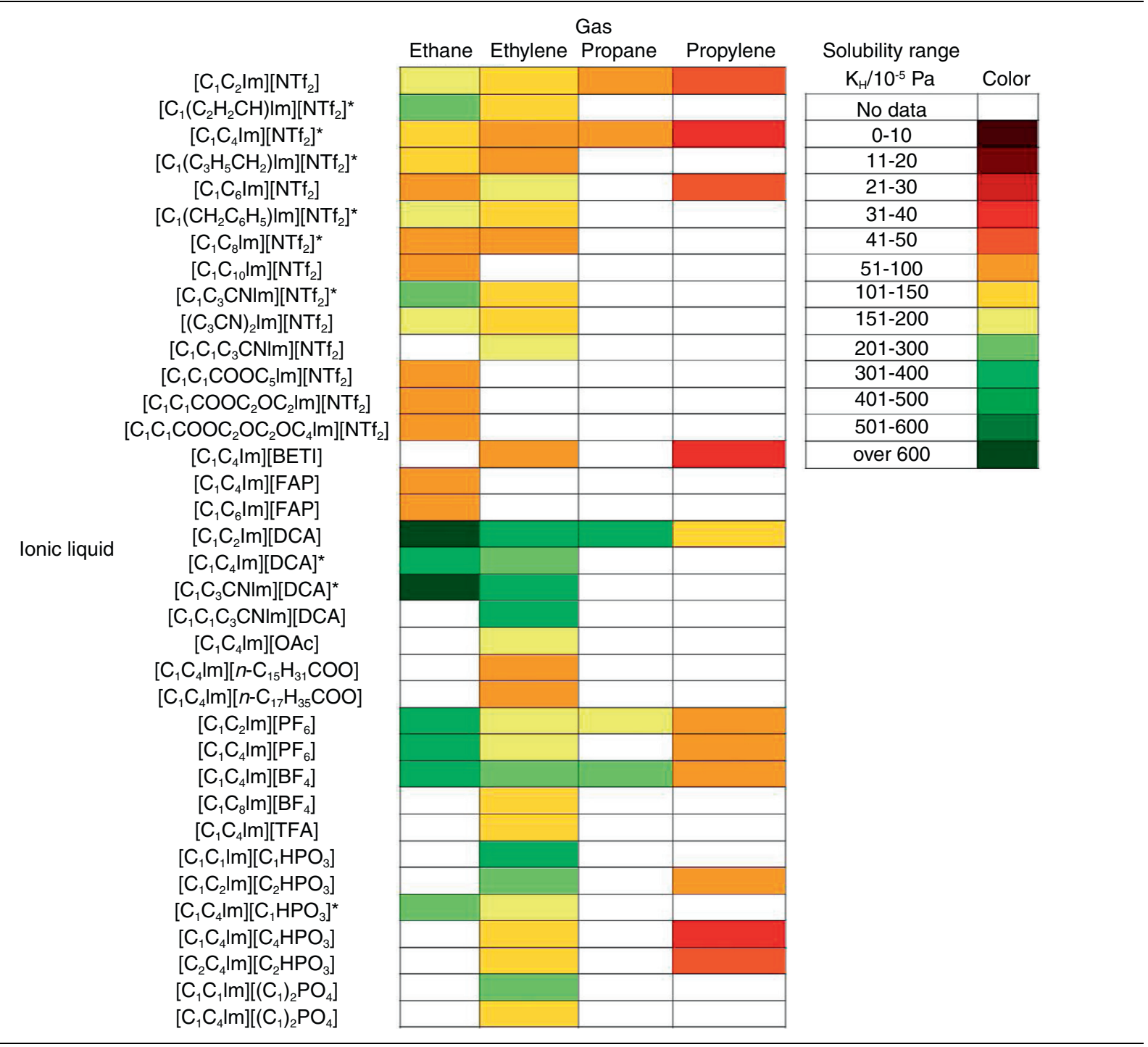

observed that the ionic liquid-silver salt solution selectivities were always higher than for $\left[\mathrm{C}_{1} \mathrm{C}_{2} \mathrm{Im}\right]\left[\mathrm{NTf}_{2}\right]$, which presents an ethylene selectivity under 2 , at $303 \mathrm{~K}$ and 1 bar. The highest selectivity was obtained for the 1.8 mol. $\mathrm{L}^{-1}$ silver solution in $\left[\mathrm{C}_{1} \mathrm{C}_{2} \mathrm{Im}\right]\left[\mathrm{CF}_{3} \mathrm{SO}_{3}{ }^{-}\right]$, with a selectivity of 100 at 1 bar and $333 \mathrm{~K}$. The authors defined selectivity as the proportion between mole of ethylene and the mole of ethane at a certain pressure.

Mortaheb et al. [32] studied the effect of temperature and silver salt concentration on the absorption of ethane and ethylene in ionic liquid $\left[\mathrm{C}_{1} \mathrm{C}_{4} \mathrm{Im}\right]\left[\mathrm{NO}_{3}\right]$. A maximum selectivity of 15 was obtained for 5 mol. $\mathrm{L}^{-1}$ silver salt at $278 \mathrm{~K}$. The authors defined selectivity as the proportion between amount of ethylene and the amount of ethane.
Faiz and Li [33] reviewed the application of ionic liquid/ metal salt composite membranes for olefin/paraffin separations. They concluded that even though the concept was successfully applied for separation, the long-term stability of the membranes is still a major issue.

A task specific ionic liquid complex salt, $\left[\mathrm{Ag}\left(\right.\right.$ olefin $_{x}$ ] $\left[\mathrm{NTf}_{2}\right]$, formed as described in Scheme 1, provided an ideal selectivity of 40, a much larger selectivity when compared to the silver salt- $\left[\mathrm{C}_{1} \mathrm{C}_{4} \mathrm{Im}\right]\left[\mathrm{BF}_{4}\right]$ solution of 16 , at $298 \mathrm{~K}$ :

$$
\mathrm{AgNTf}_{2} \stackrel{\text { olefin }}{\longrightarrow}\left[\mathrm{Ag}(\text { olefin })_{\chi}\left[\mathrm{NTf}_{2}\right]\right.
$$

Scheme 1

Synthesis of ionic liquid $\left[\operatorname{Ag}(\text { olefin })_{x}\right]\left[\mathrm{NTf}_{2}\right]$. 
TABLE 4

Solubility of ethane, ethylene, propane and propylene in several ionic liquids expressed in Henry's law constant, $\mathrm{K}_{\mathrm{H}}$, the majority at $313 \mathrm{~K}$

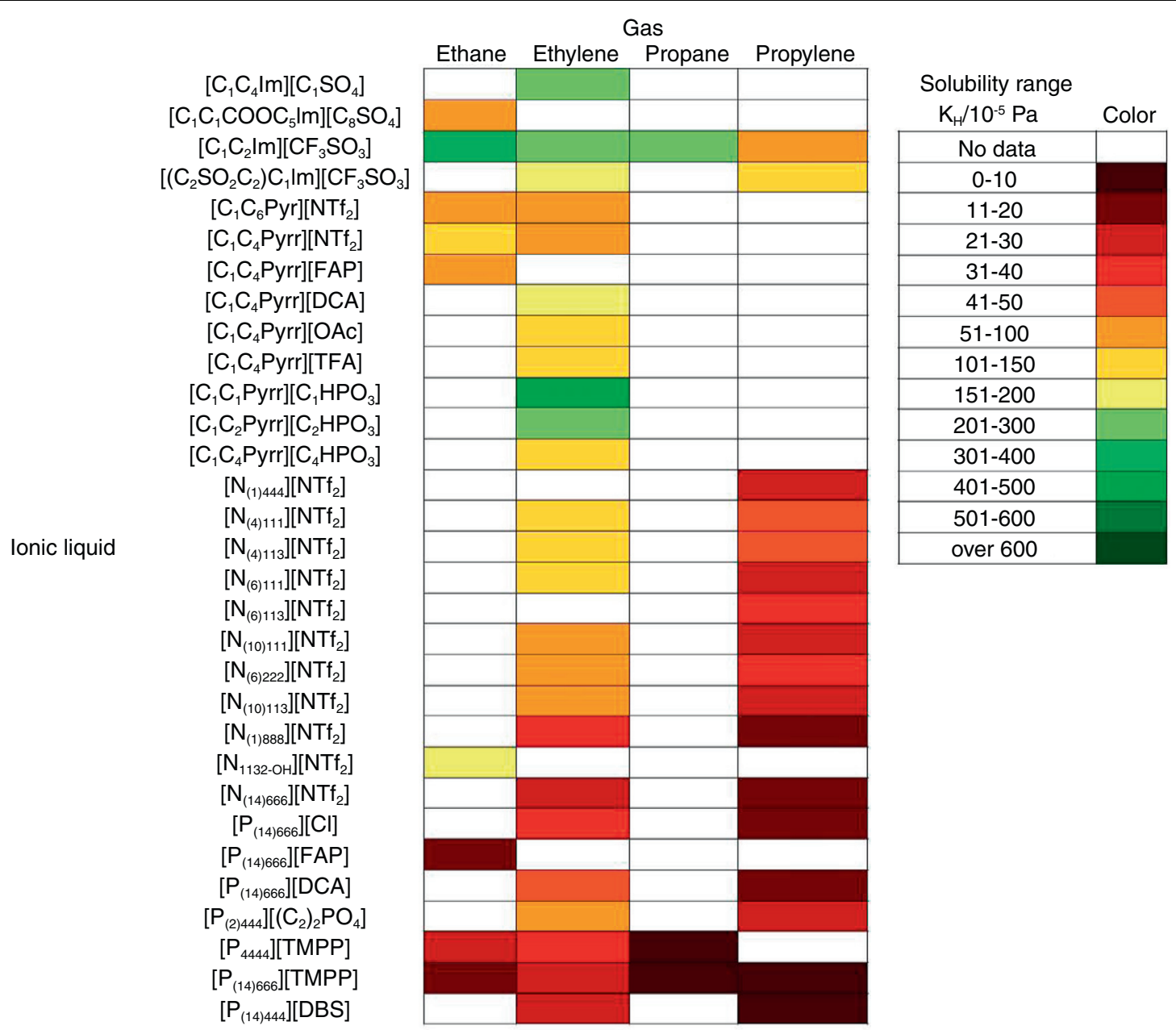

This salt was also successfully used to create an adaptive self-healing propane/propene separation membrane, although the details of its long term stability were not provided [34, 35].

Ortiz et al. [36] studied the selective absorption of propylene from propane/propylene mixtures in $\left[\mathrm{C}_{1} \mathrm{C}_{4} \mathrm{Im}\right]\left[\mathrm{BF}_{4}\right]$ with, and without, silver ions, at several temperatures and pressures. They demonstrated that the propylene selectivity is less than 3 in absence of the silver salt in the ionic liquid and 8 to 16 upon addition of 0.25 mol. $\mathrm{L}^{-1}$ silver salt in the ionic liquid at $298 \mathrm{~K}$ and between 1 and 3 bar. Higher pressures proved to lower the selectivity for the silver salt containing ionic liquid, probably due to the saturation of the silver ions. The propylene absorption capacity for the ionic liquids-silver salt solution was compared to aqueous solutions with the same silver salt concentration and it was found that the aqueous solutions presented lower propylene capacities. Although allowing the increase of the capacity and selectivity of the selected support for the unsaturated gas, the use of metals presents drawbacks due to their cost, contamination, degradation, safety problems, limited metal salt solubility and high viscosities of the resulting liquid absorbent [26, 35, 37, 38, 39].

A detailed engineering analysis is out of the scope of the present paper but would most certainly be necessary in order to properly compare these new technologies based on the use of ionic liquids with traditional processes such as cryogenic distillation. Although costs may considerably vary with time, the current process is so expensive energetically and presents such a negative environmental impact that the detailed analysis of possible alternatives is very pertinent.

\section{CONCLUSIONS AND PERSPECTIVES}

Contrary to what is suggested in the literature, the solubility of unsaturated gases, such as ethylene and propylene in ionic liquids is not always higher than of their saturated 
counterparts, ethane and propane. In fact, their solubility ranges overlap. As can be seen in Figure 7, this fact is true independently of the way the gas solubility is expressed in mole fraction, per mass or per volume of solvent.

The tendencies observed for ethane, ethylene, propane and propylene are similar. The solubility of these gases increases with the size of the non-polar domains of the cation or anion of the ionic liquid, suggesting that the solubility of these gases in the group of ionic liquids studied is ruled by nonspecific interactions. The solubility order in terms of cations is:

$$
\mathrm{P}_{n m p q}{ }^{+}>\mathrm{C}_{n} \mathrm{Pyr}^{+}>\mathrm{C}_{n} \mathrm{C}_{m} \mathrm{Pyrr}^{+}>\mathrm{C}_{n} \mathrm{C}_{m} \mathrm{Im}^{+}
$$

In comparison, the solubility dependency in terms of the nature of the anion is much smaller, for the same gases.

It would be of great interest to develop ionic liquids containing functionalizations or anions (such as $\mathrm{AlCl}_{4}{ }^{-}$) that could promote a specific interaction with ethylene or propylene. Another promising possibility is to develop ionic liquids containing metal ions in their structure [40]. However, the more specific are the interactions between the gas and the ionic liquid, the harder the recycling of the absorbent will be, and a balancing effect between specificity and recovery should be taken into account on the development of an ionic liquid for separation purposes.

The published solubility data on ethane, ethylene, propane and propylene $(\mathrm{Tab} .3,4)$ provides a good start on a database in light hydrocarbon solubility in ionic liquids. This information can be used as a good basis for the development of a model that would allow the prediction of the solubility of these gases in other ionic liquids.

\section{ACKNOWLEDGMENTS}

The authors thank Dr. Y. Chauvin (Emerit Research Director 1995-2015 at C2P2, Équipe COMS, Lyon) for the insightful discussions in the early stages of this project.

L.M. was financed by a Cluster Excellence of the RhôneAlpes region with the participation of IFPEN. The authors thank Dr Méthivier of IFPEN for fruitful discussions during this project.

\section{REFERENCES}

1 Henley E.J., Seader J.D., Roper D.K. (2011) Separation Process Principles, Third Edition, Jonh Wiley \& Sons.

2 Jacquemin J., Costa Gomes M.F., Husson P., Majer V. (2006) Solubility of Carbon Dioxide, Ethane, Methane, Oxygen, Nitrogen, Hydrogen, Argon, and Carbon Monoxide in 1-Butyl-3-methylimidazolium Tetrafluoroborate Between Temperatures $283 \mathrm{~K}$ and $343 \mathrm{~K}$ and at Pressures Close to Atmospheric, J. Chem. Thermodyn. 38, 490-502.
3 Hu Y., Liu Z., Xu C., Zhang X. (2011) The Molecular Characteristics Dominating the Solubility of Gases in Ionic Liquids, Chem. Soc. Rev. 40, 3802-3823

4 Lei Z., Dai C., Chen B. (2014) Gas Solubility in Ionic Liquids, Chem. Rev. 114, 1289-1326.

5 Olivier-Bourbigou H., Magna L., Morvan D. (2010) Ionic liquids and catalysis: Recent progress from knowledge to applications, Appl. Catal. A-Gen. 373, 1-56.

6 Armand M., Endres F., MacFarlane D.R., Ohno H., Scrosati B. (2009) Ionic-liquid materials for the electrochemical challenges of the future, Nat. Mater. 8, 621-629.

7 Han D., Row K.H. (2010) Recent Applications of Ionic Liquids in Separation Technology, Molecules 15, 2405-2426.

8 Hong G., Jacquemin J., Deetlefs M., Hardacre C., Husson P., Costa Gomes M.F. (2007) Solubility of Carbon Dioxide and Ethane in Three Ionic Liquids Based on the Bis \{(trifluoromethyl) sulfonyl \}imide Anion, Fluid Phase Equilibr. 257, 27-34.

9 Camper D., Becker C., Koval C., Noble R. (2005) Low Pressure Hydrocarbon Solubility in Room Temperature Ionic Liquids Containing Imidazolium Rings Interpreted Using Regular Solution Theory, Ind. Eng. Chem. Res. 44, 1928-1933.

10 Camper D., Scovazzo P., Koval C., Noble R. (2004) Gas Solubilities in Room-Temperature Ionic Liquids, Ind. Eng. Chem. Res. 43, 3049-3054.

11 Kilaru P.K., Scovazzo P. (2008) Correlations of Low-Pressure Carbon Dioxide and Hydrocarbon Solubilities in Imidazolium-, Phosphonium-, and Ammonium-Based Room-Temperature Ionic Liquids. Part 2. Using Activation Energy of Viscosity, Ind. Eng. Chem. Res. 47, 910-919.

12 Kilaru P.K., Condemarin R.A., Scovazzo P. (2008) Correlations of Low-Pressure Carbon Dioxide and Hydrocarbon Solubilities in Imidazolium-, Phosphonium-, and Ammonium-Based Room-Temperature Ionic Liquids. Part 1. Using Surface Tension, Ind. Eng. Chem. Res. 47, 900-909.

13 Morgan D., Ferguson L., Scovazzo P. (2005) Diffusivities of Gases in Room-Temperature Ionic Liquids: Data and Correlations Obtained Using a Lag-Time Technique, Ind. Eng. Chem. Res. 44, 4815-4823.

14 Liu X., Afzal W., Yu G., He M., Prausnitz J.M. (2013) High Solubilities of Small Hydrocarbons in Trihexyl Tetradecylphosphonium Bis(2,4,4-trimethylpentyl) Phosphinate, J. Phys. Chem. B 117, 10534-10539.

15 Gan Q., Zou Y., Rooney D., Nancarrow P., Thompson J., Liang L., Lewis M. (2011) Theoretical and Experimental Correlations of Gas Dissolution, Diffusion, and Thermodynamic Properties in Determination of Gas Permeability and Selectivity in Supported Ionic Liquid Membranes, Adv. Colloid Interfac. 164, 45-55.

16 Xing H., Zhao X., Li R., Yang Q., Su B., Bao Z., Yang Y., Ren Q. (2013) Improved Efficiency of Ethylene/Ethane Separation Using a Symmetrical Dual Nitrile-Functionalized Ionic Liquid, ACS Sustainable Chem. Eng. 1, 1357-1363.

17 Anthony J.L., Anderson J.L., Maginn E.J., Brennecke J.F. (2005) Anion Effects on Gas Solubility in Ionic Liquids, J. Phys. Chem. B 109, 6366-6374.

18 Zhang J., Zhang Q., Qiao B., Deng Y. (2007) Solubilities of the Gaseous and Liquid Solutes and Their Thermodynamics of Solubilization in the Novel Room-Temperature Ionic Liquids at Infinite Dilution by Gas Chromatography, J. Chem. Eng. Data 52, 2277-2283. 
19 Zhang Q., Li Z., Zhang J., Zhang S., Zhu L., Yang J., Zhang X., Deng Y. (2007) Physicochemical Properties of NitrileFunctionalized Ionic Liquids, J. Phys. Chem. B 111, 2864-2872.

20 Palgunadi J., Kim H.S., Lee J.M., Jung S. (2010) Ionic Liquids for Acetylene and Ethylene Separation: Material Selection and Solubility Investigation, Chem. Eng. Process. 49, 192-198.

21 Costa Gomes M.F. (2007) Low-Pressure Solubility and Thermodynamics of Solvation of Carbon Dioxide, Ethane, and Hydrogen in 1-Hexyl-3-methylimidazolium Bis(trifluoromethylsulfonyl)amide between Temperatures of $283 \mathrm{~K}$ and $343 \mathrm{~K}$, J. Chem. Eng. Data 52, 472-475.

22 Anthony J.L., Maginn E.J., Brennecke J.F. (2002) Solubilities and Thermodynamic Properties of Gases in the Ionic Liquid 1-n-Butyl-3-methylimidazolium Hexafluorophosphate, J. Phys. Chem. B 106, 7315-7320.

23 Liu X., Ruiz E., Afzal W., Ferro V., Palomar J., Prausnitz J.M. (2014) High Solubilities for Methane, Ethane, Ethylene, and Propane in Trimethyloctylphosphonium Bis(2,4,4-trimethylpentyl) Phosphinate ([P8111][TMPP]), Ind. Eng. Chem. Res. 53, 363-368.

24 Anderson J.L., Dixon J.K., Brennecke J.F. (2007) Solubility of $\mathrm{CO}_{2}, \mathrm{CH}_{4}, \mathrm{C}_{2} \mathrm{H}_{6}, \mathrm{C}_{2} \mathrm{H}_{4}, \mathrm{O}_{2}$, and $\mathrm{N}_{2}$ in 1-Hexyl-3-methylpyridinium Bis(trifluoromethylsulfonyl)imide: Comparison to Other Ionic Liquids, Acc. Chem. Res. 40, 1208-1216.

25 Liu X., Afzal W., Prausnitz J.M. (2013) Solubilities of Small Hydrocarbons in Tetrabutylphosphonium Bis(2,4,4-trimethylpentyl) Phosphinate and in 1-Ethyl-3-methylimidazolium Bis (trifluoromethylsulfonyl)imide, Ind. Eng. Chem. Res. 52, 14975-14978.

26 Safarik D.J., Eldridge R.B. (1998) Olefin/Paraffin Separations by Reactive Absorption: A Review, Ind. Eng. Chem. Res. 37, 2571-2581.

27 Moura L., Mishra M., Bernales V., Fuentealba P., Padua A.A.H., Santini C.C., Costa Gomes M.F. (2013) Effect of Unsaturation on the Absorption of Ethane and Ethylene in Imidazolium-Based Ionic Liquids, J. Phys. Chem. B 117, 7416-7425.

28 Moura L., Darwich W., Santini C.C., Costa Gomes M.F. (2015) Imidazolium-based ionic liquids with cyano groups for the selective absorption of ethane and ethylene, Chem. Eng. J. 280, 755-762.

29 Green B.D., O’Brien R.A., Davis Jr. J.H., West K.N. (2015) Ethane and Ethylene Solubility in an Imidazolium-Based Lipidic Ionic Liquid, Ind. Eng. Chem. Res. 54, 5165-5171.
30 Moura L. (2014) Ionic liquids for the separation of gaseous hydrocarbons, PhD Thesis, Université Lyon 1.

31 Sánchez L.M.G., Meindersma G.W., Haan A.B. (2009) Potential of Silver-Based Room-Temperature Ionic Liquids for Ethylene/Ethane Separation, Ind. Eng. Chem. Res. 48, 10650-10656.

32 Mortaheb H.R., Mafi M., Mokhtarani B., Sharifi A., Mirzaei M., Khodapanah N., Ghaemmaghami F. (2010) Experimental Kinetic Analysis of Ethylene Absorption in Ionic Liquid $\left.[\mathrm{Bmim}] \mathrm{NO}_{3}\right]$ with Dissolved $\mathrm{AgNO}_{3}$ by a Semi-Continuous Process, Chem. Eng. J. 158, 384-392.

33 Faiz R., Li K. (2012) Olefin/Paraffin Separation Using Membrane Based Facilitated Transport/Chemical Absorption Techniques, Chem. Eng. Sci. 73, 261-284.

34 Pitsch F., Krull F.F., Agel F., Schulz P., Wasserscheid P., Melin T., Wessling M. (2012) An Adaptive Self-Healing Ionic Liquid Nanocomposite Membrane for Olefin-Paraffin Separations, Adv. Mater. 24, 4306-4310.

35 Agel F., Pitsch F., Krull F.F., Schulz P., Wessling M., Melin T., Wasserscheid P. (2011) Ionic Liquid Silver Salt Complexes for Propene/Propane Separation, Phys. Chem. Chem. Phys. 13, 725-731.

36 Ortiz A., Ruiz A., Gorri D., Ortiz I. (2008) Room Temperature Ionic Liquid with Silver Salt as Efficient Reaction Media for Propene/Propane Separation: Absorption Equilibrium, Sep. Purif. Technol. 63, 311-318.

37 Staudt-Bickel C., Koros W.J. (2000) Olefin/paraffin Gas Separations with 6FDA-Based Polyimide Membranes, J. Membrane Sci. 170, 205-214.

38 Morisato A., He Z., Pinnau I., Merkel T.C. (2002) Transport Properties of PA12-PTMO/AgBF 4 Solid Polymer Electrolyte Membranes for Olefin/Paraffin Separation, Desalination 145, 347-351.

39 Hsiue G., Yang J. (1993) Novel Methods in Separation of Olefin/Paraffin Mixtures by Functional Polymeric Membranes, J. Membrane Sci. 92, 117-128.

40 Lin I.J.B., Vasam C.S. (2005) Metal-Containing Ionic Liquids and Ionic Liquid Crystals Based on Imidazolium Moiety, J. Organomet. Chem. 690, 3498-3512.

Manuscript submitted in September 2015

Manuscript accepted in November 2015

Published online in March 2016

Cite this article as: L. Moura, C.C. Santini and M.F.C. Gomes (2016). Gaseous Hydrocarbon Separations Using Functionalized Ionic Liquids, Oil Gas Sci. Technol 71, 23. 